\title{
Research Paper: Comparison of Behavioral Problems and Skills of 7-12-Year-Old Students With a Physical/Motor Disability at Mainstream and Special Schools
}

\author{
Tahereh Hendi ${ }^{1}$, Sahel Hemmati Garakani ${ }^{2 *}$, Narges Adibsereshki ${ }^{1,2}$, Robab Teymouri ${ }^{2}$, Samaneh Hosseinzadeh
}

1. Department of Psychology and Education of Exceptional Children, University of Social Welfare and Rehabilitation Sciences, Tehran, Iran 2. Pediatric Neurorehabilitation Research Center, University of Social Welfare and Rehabilitation Sciences, Tehran, Iran.

3. Department of Biostatistics, University of Social Welfare and Rehabilitation Sciences, Tehran, Iran.

\begin{tabular}{|l|l|l}
\hline $\begin{array}{l}\text { Use vour device to san } \\
\text { and read the article online }\end{array}$ & $\begin{array}{l}\text { Citation: Hendi T, Hemmati Garakani S, Adibsereshki N, Teymouri R, Hosseinzadeh S. Comparison of Behavioral Problems } \\
\text { and Skills of 7-12-Year-Old Students with a Physical/Motor Disability at Mainstream and Special Schools. Iranian Rehabilitation } \\
\text { Journal. 2018; 16(1):91-102. ttps://doi.org/10.29252/NRIP.IRJ.16.1.91 }\end{array}$ \\
doi : $:$ https://doi.org/10.29252/NRIP.IRJ.16.1.91
\end{tabular}

Article info:

Received: 14 Apr. 2017

Accepted: 02 Aug. 2017

\section{Keywords:}

Physical/motor disability, Mainstream and special schools, Behavioral problems and skills

\section{A B S T RACT}

Objectives: This study aimed to compare the behavioral problems and abilities of 7-12-yearold students with a physical/motor disability at mainstream and special schools.

Methods: The data in this comparative (cross sectional-analytic) study were collected using total population sampling, A sample of 247 students with a physical/motor disability including 153 students ( 67 females and 86 males) at special schools and 94 students (41 females and 53 males) at mainstream schools participated in this study. Data were collected using the Teacher and Parents versions of the child's Strengths and Difficulties Questionnaire (SDQ). Each version includes five aspects, namely, emotional symptoms, conduct problems, attention deficit / hyperactivity disorder, peer relationship problems for measuring behavioral problems and the Prosocial Behaviors Questionnaire for estimating behavioral skills. Data analysis was performed using non-parametric Man-Whitney U and Kruskal-Wallis tests.

Results: Students with a physical/motor disability studying at mainstream schools significantly differed from those studying at special schools in terms of behavioral problems $(\mathrm{P}<0.05)$. The obtained mean scores revealed that the students' behavioral problems were less frequent at mainstream schools and more common at special schools. Based on teachers' viewpoints, there was a significant difference in behavioral skills among students with a physical/motor disability at mainstream and special schools. However, according to parents, there was no significant difference in behavioral skills between students at both schools.

Discussion: Our data demonstrate that behavioral problems of students with a physical/motor disability are fewer in mainstream schools indicating stronger behavior skills than their peers in special schools. In view of our data, we recommend the possibility of integrating the education of special needs students at regular schools.

* Corresponding Author: 


\section{Introduction}

A

ccording to the American Health Association, a child with a disability is a child who, for various reasons, cannot fully actualize all his physical, mental and social potentials. In other words, a child cannot play, learn or perform other activities as his peers do [1]. One type of disability is physical/motor disability that refers to any type of problem including weakness, disability or disorder in one's motor system and in need of a mobility aid [2]. According to the Americans with Disabilities Act of 1990, a physical-motor disability is defined as a disorder significantly limiting one or more of the major life activities [3]. According to the statistics provided by the United States Statistics Department (2000), about 21.2 million people, i.e. $8.2 \%$ of the general population have specific physical/motor disabilities [4]. With regards to their frequency, although physical/motor disabilities display low occurrence, they are present in various conditions among children with special needs. Cerebral palsy is the most common and well-known type of injury in school-age children with physical/motor disabilities while other types of disorders include spina bifida and spinal cord injury [5].

Children with disabilities exhibit various types of unfavorable behavioral patterns. Research has shown that students with low intellectual, physical and visual skills are more likely to present with behavioral problems than their non-disabled peers. The occurrence of behavioral problems is associated with the severity of the physi$\mathrm{cal} /$ motor disability. Feelings of anxiety, fear, isolation, aggression, introversion, and humiliation are the most prominent behavioral issues among these children [6].

Children with physical/motor disabilities often associate their physical appearance as the psychological and social causes of depression [7]. Jones and Lollar showed that young people with a physical-motor disability are more likely to be at risk because of poor health outcomes and that many students with a physical/motor disability are hopeless, sad, and disappointed compared to their peers leading them to give up per-forming some routine activities [8]. Bjorgaas, Elgen, Boe and Hysing indicated that anxiety and depression, behavioral difficulties and attention deficit/hyperactivity are more common in children with cerebral palsy than their normal peers, resulting in a feeling of weakness among the former [9]. Brossard-Racine et al. estimated that the prevalence of behavioral struggles in primary school children with cerebral palsy is approximately $40 \%$ and that specific behavioral concerns such as poor interaction with peers, emotional symptoms and attention deficit/hyperactivity are obvious in one-third of those affected [10].

In many instances, children with physical/motor disability are deprived of attending regular schools due to the severity of their impairment and attend a special school to receive complementary support in the classroom. However, sometimes, these children can participate in a mainstream school and attend classes along with their non-disabled peers [11]. Special education is a unique and important educational opportunity that is unlike any other instructional method, wherein students' special needs and requirements are individually met, and each student would somehow be taught using distinctive techniques and methods [12]. This schooling method is designed to enhance the educational outcomes for students with disabilities, and a limited degree of expertise and professional services are provided based on their unique needs in an individualized environment [13].

These schools are reserved for students with a physicalmotor disability, including children with cerebral palsy as this system provides the best possible care by instructors and trained teachers in addition to appropriate equipment for the children. These exclusive education facilities are benefitting for children with cerebral palsy enabling them to be trained and treated equally. The most important argument to support special education is the expertise and equipment found in these schools. Furthermore, special education instructors have not only received the necessary training pertaining to the pedagogical success of the children but also have access to specialized equipment for the type of teaching required to achieve educational progress in children with cerebral palsy [14].

In recent decades, the role of special schools has been challenged by the concept of inclusive education where children identified with special educational needs should be able to attend regular schools along with their peers to participate in meaningful learning activities [15]. The widespread acceptance of inclusion has enhanced the number of students with disabilities in the public education system over the past years along with an increased the number of students with a physical/motor disability attending regular schools [16]. Many professionals believe that physically disabled children and young people should have the same opportunities and experiences of making friends, playing, spending leisure time and having access to recreational facilities as others. They too like to have friends of the same age and to share similar experiences with their peers, suggesting that these children can participate in the activities of mainstream schools [17]. In general, research shows that various 
types of programs, both in special education and inclusive education, would result in relatively positive scientific and social effects for such students [18].

Differences in educational systems and basic education can also result in different outcomes for these students [19]. Although children with physical/motor disability spend a major part of their day in the school environment, limited research has been devoted to the behavioral issues faced by these students. Studies on the psychosocial measurement and assessment of children with physical/motor disability, researchers tend to provide little information about social and behavioral skills through extensive measures and tools. Goodman et al. showed that the Strength and Difficulties Questionnaire (SDQ) can be used by parents, teachers and students as a tool for knowledge and assessment and for the detection of strengths, problems and mental and behavioral disorders, and thus access to effective treatment [20].

Considering the different approaches in the educational systems for children with a physical/motor disability and with regards to the strengths and weaknesses of each approach, the present study aimed to compare the two systems to determine which one is more effective in reducing the behavioral problems of students with special needs. To this end, the behavioral problems and skills of students with a physical-motor disability were identified at mainstream and special schools using the SDQ to better compare these two educational systems Our main research objective in this study was to determine if there is any difference in behavioral problems female and male students with a physical/motor disability at mainstream and special schools.

\section{Methods}

\section{Participants}

The data in this comparative (cross sectional-analytic) study was collected using total population sampling. The statistical population included all students with a physi$\mathrm{cal} /$ motor disability studying at mainstream and special schools of Tehran in the academic year of 2016-2017. It contained 768 students (358 girls and 410 boys) among whom 483 samples (221 girls and 262 boys) were studying at elementary school. The inclusion and exclusion criteria in this study were as follows: aged 7 to 12 years old, borderline and above intellectual function (determined based on test records in the students' files), student enrollment since the beginning of the school year, lack of simultaneous physical life-threatening diseases such as epilepsy and diabetes, lack of any developmental coordination disorders and tick disorders, not suffering from more than one disability such as low intelligence and sensory problems (blindness and deafness) and failure to complete the questionnaire. The final research sample size consisted of 247 students with a physical/ motor disability, aged 7 to 12 years, studying at the elementary level in mainstream and special schools of Tehran in the academic year of 2016-2017. The participants in this study consisted of 153 students (67 girls and 86 boys) from special schools and 94 students (41 girls and 53 boys) from mainstream schools.

An initial meeting was held with the parents and teachers of the participating students where they were provided with a detailed description of the study. After receiving their informed consent to participate in the study, they were given a questionnaire and were advised to be precise in answering the questionnaire and choosing the best option, while also directing any questions they had, if any, to the researcher.

\section{Measurements}

In order to collect accurate information, the teacher-andparents version of each child's Strengths and Difficulties Questionnaire (SDQ) was used. The SDQ is a short behavioral screening scale that is used for children aged 3 to 16 years. The questionnaire was developed by Goodman (1997) in England based on ICD-10 diagnostic criteria [21]. It has three forms/versions: Teacher version for students aged 4-16 years old; Parents version for children aged 4-16 and 3-16 years old; and a self-report version for students aged 11-16 years old which is based on one's understanding and knowledge of self [22]. This questionnaire has 25 items assessing the positive and negative aspects of conduct and behavior. The 25 items are relevant to five aspects: emotional symptoms ( 5 items), behavioral problems (items 5), attention deficit/hyperactivity disorder (5 items), prosocial behaviors (5 items) and communication problems (5 items), based on which a total score of behavioral problems is obtained [23].

The SPSS statistical software was used to analyze the data. To this end, the descriptive statistics (frequency, mean, standard deviation) and inferential statistics (Mann-Whitney and Kruskal-Wallis) were used at a significance level of $\mathrm{P}<0.05$.

\section{Ethics statement}

This study followed all the ethics rules according to the International Ethics Guidelines for Research and Publishing and this project was approved with reference to the code 
IR.USWR.REC.1396.5 by the Ethics Committee of the University of Social Welfare and Rehabilitation Sciences.

\section{Results}

This study aimed to compare the role of mainstream and special schools on the problems and behavioral skills of 7-12-year-old students with a physical/motor disability. A sample of 247 students with a physical/motor disability including 153 students (67 females and 86 males; $61.9 \%$ ) at special schools and 94 students (41 females and 53 males; $38.1 \%$ ) at mainstream schools participated in this study (Table 1). The female and male students in the mainstream schools were 41(43.6\%) and 53(56.4\%), respectively. The number of female students at special schools was $67(43.8 \%)$ and the number of boys at special schools was $86(56.2 \%)$. The students aged between 7 and 12 years old, with a mean age of 9.29 years and were divided into three age groups of 7-8, 9-10 and 1112 years old. Students were selected from all regions of the city (i.e. North, West, East, South, and Downtown).

Table 2 compares the behavioral problems and abilities of students with a physical/motor disability at mainstream and special schools. The mean scores of students' behavioral problems, emotional symptoms, attention deficit/ hyperactivity disorder, peer relationship problems and general behavioral problems differed significantly at mainstream and special schools from both teachers and parents perspectives $(\mathrm{P}<0.05)$. The mean scores obtained indicated that the behavioral problems of students at mainstream schools were less than those observed at special schools.

In addition, the mean scores of students' prosocial behaviors at mainstream and special schools were significantly different $(\mathrm{P}<0.05)$ and the prosocial behaviors were more frequent at mainstream schools (7.22 at main- stream schools vs. 6.35 at special schools) as inferred from their teachers' perspective. However, there was no significant difference between the mean scores of prosocial behaviors at main-stream and special schools according to the parents.

Our data demonstrate that female and male students at both schools were significantly different from the teachers and parents' perspectives in some behavioral problems scales. These differences were significant in terms of attention deficit/hyperactivity and all scales of behavioral problems $(\mathrm{P}<0.05)$. According to the mean scores, attention deficit/hyperactivity and total scale of behavioral problems were lower among female students of mainstream schools, and behavioral problems were less common among male students at mainstream schools than those at special schools (Table 3).

According to the teachers, emotional symptoms and behavioral problems of the female students at both schools differed significantly. The mean scores obtained revealed that the emotional symptoms and behavioral problems were less common among the female students of mainstream schools than their counterparts at special schools. Even though parents' views reflected that the emotional symptoms and conduct problems of female students at both schools were not significantly different, the parents perceived that there was a significant difference in terms of peer relationship problems for female students at both schools and peer relationship problems among female students of mainstream schools was less observed (1.29 vs. 2.34). The mean scores of prosocial behaviors of female students at both schools were not significantly different from both teachers and parents' perspectives.

According to the teachers and parents, emotional symptoms of the male students at both schools did not

Table 1. Distribution of participants in terms of school type, gender and age

\begin{tabular}{cccc}
\hline Variable & Grouping & Number & Percent \\
\hline \multirow{2}{*}{ Type of school } & Mainstream & 94 & 38.1 \\
& Exceptional & 153 & 61.9 \\
Gender & Female & 108 & 43.7 \\
& Male & 139 & 56.3 \\
Age category & $7-8$ Years & 77 & 31.2 \\
& $9-10$ Years & 79 & 32.0 \\
\hline
\end{tabular}


Table 2. Differences in behavioral problems and abilities between students with a physical/motor disability at mainstream and special schools

\begin{tabular}{|c|c|c|c|c|c|c|c|c|}
\hline \multirow{2}{*}{ SDQ Scale } & & \multicolumn{2}{|c|}{$\begin{array}{l}\text { Mainstream Schools } \\
\quad(n=94)\end{array}$} & \multicolumn{2}{|c|}{$\begin{array}{l}\text { Special Schools } \\
\text { ( } n=153)\end{array}$} & \multirow{2}{*}{ U } & \multirow{2}{*}{ Z } & \multirow{2}{*}{$\mathbf{P}$} \\
\hline & & M & SD & M & SD & & & \\
\hline \multirow{2}{*}{$\begin{array}{l}\text { Emotional } \\
\text { symptoms }\end{array}$} & Teacher rating & 1.72 & 1.970 & 2.30 & 2.239 & 6167 & -1.999 & 0.055 \\
\hline & Parent rating & 2.41 & 2.516 & 2.84 & 2.659 & 6466 & -1.350 & 0.177 \\
\hline \multirow{2}{*}{$\begin{array}{l}\text { Conduct prob- } \\
\text { lems }\end{array}$} & Teacher rating & 0.82 & 1.107 & 1.67 & 1.626 & 6484.5 & -4.479 & 0.0000 \\
\hline & Parent rating & 0.89 & 1.205 & 1.77 & 1.587 & 4724.5 & -4.479 & 0.0000 \\
\hline \multirow{2}{*}{ ADHD } & Teacher rating & 2.35 & 2.188 & 4.34 & 2.594 & 3978 & -5.940 & 0.0000 \\
\hline & Parent rating & 3.06 & 2.594 & 4.93 & 2.640 & 4336.5 & -5.268 & 0.0000 \\
\hline \multirow{2}{*}{ Peer problems } & Teacher rating & 1.64 & 1.728 & 2.27 & 1.784 & 5617 & -2.942 & 0.003 \\
\hline & Parent rating & 1.24 & 1.471 & 2.41 & 1.771 & 4288.5 & -5.428 & 0.0000 \\
\hline \multirow{2}{*}{$\begin{array}{l}\text { Total behav- } \\
\text { ioral problems } \\
\text { score }\end{array}$} & Teacher rating & 6.53 & 5.673 & 10.58 & 6.291 & 4445 & -5.043 & 0.0000 \\
\hline & Parent rating & 7.62 & 6.070 & 11.94 & 6.606 & 4457.5 & -5.022 & 0.0000 \\
\hline \multirow{2}{*}{$\begin{array}{l}\text { Prosocial } \\
\text { behaviors }\end{array}$} & Teacher rating & 7.22 & 2.291 & 6.35 & 2.429 & 5716 & -2.730 & 0.006 \\
\hline & Parent rating & 7.11 & 2.045 & 6.63 & 2.814 & 6759 & -0.799 & 0.424 \\
\hline
\end{tabular}

Iranian Rehabilitation Journal

differ significantly. However, the mean scores of prosocial behaviors significantly differed among the male students at both schools according to the teachers and it was observed that the male students in mainstream classes displayed more frequent prosocial behaviors in (7.09 vs. 5.90). Interestingly, no similar observation was reported by the parents.

Table 4 compares the behavioral problems and abilities of female students with a physical/motor disability at mainstream schools based on their age groups. Table 4 shows that female students studying at mainstream schools were not significantly different in terms of behavioral problems as viewed by teachers and parents $(\mathrm{P}>0.05)$

The mean scores of behavioral problems and abilities for female students with a physical/motor disability at special schools is shown in Table 4. The data indicate differences in some scales of behavioral problems as viewed by the teachers and parents. However, this difference was not in terms of emotional symptoms, conduct problems, attention deficit/hyperactivity and total scales of behavioral problems. Also, according to the caregivers' opinions, there was no effect of age on the mean scores of emotional symptoms, conduct problems, atten- tion deficit/hyperactivity, and total scales of behavioral problems among the female students at special schools.

Meanwhile, according to the teachers, there was a significant difference in terms of peer relationship problems and prosocial behaviors among girls enrolled in special schools at different age groups. Based on the mean scores, the peer relationship problems among girls attending special schools were more frequent in the age group of 9-10 years (10.3) than other age groups. On the contrary, the parents' responses did not provide significant differences for the same behavioral aspect.

Similarly, teachers revealed that a significant difference existed in terms of prosocial behaviors among female students of special schools at different age group, where based on the mean scores, prosocial behavior among girls aged 11-12 years (7.83) was more frequent than those in other age groups, while the parents did not share the same viewpoint.

Table 5 compares the behavioral problems and abilities of male students with a physical/motor disability at both schools based on their age groups. Our results show that male students studying at mainstream and special schools were not significantly different in terms of the 
Table 3. Gender-specific differences in behavioral problems and abilities in students with a physical/motor disability at mainstream and special schools

\begin{tabular}{|c|c|c|c|c|c|c|c|c|c|}
\hline \multirow{2}{*}{ SDQ Scale } & & & \multicolumn{2}{|c|}{$\begin{array}{l}\text { Mainstream } \\
\text { Schools }\end{array}$} & \multicolumn{2}{|c|}{ Special Schools } & \multirow[t]{2}{*}{$\mathbf{U}$} & \multirow[t]{2}{*}{ Z } & \multirow[t]{2}{*}{$\mathbf{P}$} \\
\hline & & & M & SD & M & SD & & & \\
\hline \multirow{5}{*}{$\begin{array}{l}\text { Emotional } \\
\text { symptoms }\end{array}$} & \multirow[b]{2}{*}{ Female } & Teacher rating & 1.59 & 2.037 & 2.37 & 2.137 & 1055 & -2.059 & 0.040 \\
\hline & & Parent rating & 2.22 & 2.564 & 2.99 & 2.683 & 1107.5 & -1.709 & 0.087 \\
\hline & \multirow{3}{*}{ Male } & Teacher rating & 1.83 & 1.929 & 2.24 & 2.301 & 2110 & -0.749 & 0.454 \\
\hline & & & & & & & & & \\
\hline & & Parent rating & 2.57 & 2.492 & 2.72 & 2.651 & 2201 & -0.343 & 0.731 \\
\hline \multirow{4}{*}{$\begin{array}{l}\text { Conduct } \\
\text { problems }\end{array}$} & \multirow{2}{*}{ Female } & Teacher rating & 0.88 & 1.308 & 1.52 & 1.599 & 989 & -2.554 & 0.011 \\
\hline & & Parent rating & 1.00 & 1.342 & 1.51 & 1.691 & 1110.5 & -1.748 & 0.081 \\
\hline & \multirow{2}{*}{ Male } & Teacher rating & 0.77 & 1.093 & 1.98 & 1.648 & 1134.5 & -3.800 & 0.0000 \\
\hline & & Parent rating & 0.81 & 1.093 & 1.98 & 1.479 & 1199 & -4.823 & 0.0000 \\
\hline \multirow{5}{*}{ ADHD } & \multirow{2}{*}{ Female } & Teacher rating & 2.34 & 2.425 & 4.39 & 2.546 & 735 & -2.282 & 0.0000 \\
\hline & & Parent rating & 3.49 & 2.899 & 4.75 & 2.389 & 1015.5 & -5.268 & 0.022 \\
\hline & & & & & & & & & \\
\hline & \multirow[b]{2}{*}{ Male } & Teacher rating & 2.36 & 2.010 & 4.30 & 2.549 & 1275.5 & -4.388 & 0.0000 \\
\hline & & Parent rating & 3.74 & 2.305 & 5.07 & 2.802 & 1160.5 & -4.883 & 0,0000 \\
\hline \multirow{5}{*}{$\begin{array}{l}\text { Peer prob- } \\
\text { lems }\end{array}$} & \multirow[b]{2}{*}{ Female } & Teacher rating & 1.83 & 1.870 & 2.21 & 1.805 & 1176 & -1.274 & 0.203 \\
\hline & & Parent rating & 1.29 & 1.504 & 2.34 & 1.746 & 882.5 & -3.172 & 0.002 \\
\hline & \multirow{3}{*}{ Male } & Teacher rating & 1.49 & 1.613 & 2.31 & 1.777 & 1643 & -2.810 & 0.005 \\
\hline & & & & & & & & & \\
\hline & & Parent rating & 1.21 & 1.459 & 2.45 & 1.800 & 1271.5 & -4.459 & 0.0000 \\
\hline \multirow{5}{*}{$\begin{array}{l}\text { Total behav- } \\
\text { ioral prob- } \\
\text { lems score }\end{array}$} & \multirow{3}{*}{ Female } & Teacher rating & 6.63 & 5.675 & 10.49 & 6.287 & 849 & -3.326 & 0.001 \\
\hline & & Dorontrating & 800 & 6775 & 1150 & 6110 & 0265 & זבר & ( \\
\hline & & 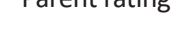 & 0.00 & $0.1 / 5$ & 11.38 & 0.448 & $9<0.3$ & -2.835 & 0.005 \\
\hline & \multirow{2}{*}{ Male } & Teacher rating & 6.45 & 5.127 & 10.64 & 6.330 & 1430.5 & -3.687 & 0.0000 \\
\hline & & Parent rating & 7.32 & 5.511 & 12.22 & 6.750 & 1307 & -4.221 & 0.0000 \\
\hline \multirow{5}{*}{$\begin{array}{l}\text { Prosocial } \\
\text { behaviors }\end{array}$} & \multirow{3}{*}{ Female } & Teacher rating & 7.39 & 2.458 & 6.93 & 2.285 & 1198 & -1.127 & 0.260 \\
\hline & & & & & & & & & \\
\hline & & Parent rating & 7.41 & 2.085 & 7.28 & 2.354 & 1357 & -0.106 & 0.916 \\
\hline & \multirow{2}{*}{ Male } & Teacher rating & 7.09 & 2.169 & 5.90 & 2.454 & 1430.5 & -3.687 & 0.006 \\
\hline & & Parent rating & 6.87 & 2.000 & 6.13 & 3.044 & 1307 & -4.221 & 0.279 \\
\hline
\end{tabular}

Iranian Rehabilitation Journa

behavioral problems based on their age groups $(\mathrm{P}>0.05)$, as perceived by the teachers and parents.

\section{Discussion}

The present study aimed to investigate the behavioral problems and abilities of students with a physical/motor disability at mainstream and special schools. Our findings suggest that the behavioral problems of disabled students were reduced and their behavioral skills were increased at mainstream schools based on the assessments of the teachers and parents. The data from this study was not consistent with the research findings of Farajullahi et al. [24] and Meshkani [25] 
Table 4. Age-specific differences in behavioral problems and abilities among female and male students with a physical/motor disability at mainstream and special schools in terms of age groups

\begin{tabular}{|c|c|c|c|c|c|c|c|c|c|c|c|}
\hline \multirow{3}{*}{ SDQ Scale } & & & \multicolumn{6}{|c|}{ Age } & \multirow{3}{*}{$x^{2}$} & \multirow{3}{*}{ df } & \multirow{3}{*}{$\mathbf{P}$} \\
\hline & & & \multicolumn{2}{|c|}{ 7-8 Years } & \multicolumn{2}{|c|}{ 9-10 Years } & \multicolumn{2}{|c|}{ 11-12 Years } & & & \\
\hline & & & M & SD & M & SD & M & SD & & & \\
\hline \multirow{4}{*}{$\begin{array}{l}\text { Emotional } \\
\text { symptoms }\end{array}$} & \multirow{2}{*}{$\begin{array}{l}\text { Mainstream } \\
\text { schools }\end{array}$} & $\begin{array}{l}\text { Teacher } \\
\text { rating }\end{array}$ & 1.25 & 1.215 & 1.94 & 2.555 & 1.36 & 1.859 & 0.360 & 2 & 0.835 \\
\hline & & $\begin{array}{l}\text { Parent } \\
\text { rating }\end{array}$ & 1.42 & 2.539 & 2.83 & 2.956 & 2.09 & 1.700 & 3.359 & 2 & 0.186 \\
\hline & \multirow{2}{*}{$\begin{array}{l}\text { Special } \\
\text { schools }\end{array}$} & $\begin{array}{l}\text { Teacher } \\
\text { rating }\end{array}$ & 1.96 & 2.116 & 2.95 & 2.259 & 2.30 & 2.141 & 2.568 & 2 & 0.277 \\
\hline & & $\begin{array}{l}\text { Parent } \\
\text { rating }\end{array}$ & 2.46 & 2.904 & 3.25 & 2.653 & 3.30 & 2.494 & 2.913 & 2 & 0.233 \\
\hline \multirow{4}{*}{$\begin{array}{l}\text { Conduct } \\
\text { problems }\end{array}$} & \multirow{2}{*}{$\begin{array}{l}\text { Mainstream } \\
\text { schools }\end{array}$} & $\begin{array}{l}\text { Teacher } \\
\text { rating }\end{array}$ & 0.33 & 0.492 & 1.33 & 1.328 & 0.73 & 1.679 & 4.102 & 2 & 0.129 \\
\hline & & $\begin{array}{l}\text { Parent } \\
\text { rating }\end{array}$ & 0.92 & 1.156 & 1.35 & 1.618 & 0.58 & 0.996 & 1.805 & 2 & 0.405 \\
\hline & \multirow{2}{*}{$\begin{array}{l}\text { Special } \\
\text { schools }\end{array}$} & $\begin{array}{l}\text { Teacher } \\
\text { rating }\end{array}$ & 0.73 & 1.679 & 2.00 & 2.309 & 1.30 & 1.265 & 0.033 & 2 & 0.984 \\
\hline & & $\begin{array}{l}\text { Parent } \\
\text { rating }\end{array}$ & 1.71 & 1.967 & 1.63 & 1.628 & 1.26 & 1.483 & 0.468 & 2 & 0.792 \\
\hline \multirow{4}{*}{ ADHD } & \multirow{2}{*}{$\begin{array}{l}\text { Mainstream } \\
\text { schools }\end{array}$} & $\begin{array}{l}\text { Teacher } \\
\text { rating }\end{array}$ & 1.75 & 1.815 & 3.00 & 2.544 & 1.91 & 2.737 & 2.646 & 2 & 0.266 \\
\hline & & $\begin{array}{l}\text { Parent } \\
\text { rating }\end{array}$ & 2.75 & 2.989 & 4.44 & 2.662 & 2.73 & 2.970 & 4.130 & 2 & 0.127 \\
\hline & \multirow{2}{*}{$\begin{array}{l}\text { Special } \\
\text { schools }\end{array}$} & $\begin{array}{l}\text { Teacher } \\
\text { rating }\end{array}$ & 4.67 & 2.761 & 5.00 & 2.428 & 3.57 & 2.293 & 3.038 & 2 & 0.219 \\
\hline & & $\begin{array}{l}\text { Parent } \\
\text { rating }\end{array}$ & 4.88 & 2.473 & 5.10 & 2.469 & 4.30 & 2.265 & 1.446 & 2 & 0.485 \\
\hline \multirow{4}{*}{$\begin{array}{l}\text { Peer prob- } \\
\text { lems }\end{array}$} & \multirow{2}{*}{$\begin{array}{l}\text { Mainstream } \\
\text { schools }\end{array}$} & $\begin{array}{l}\text { Teacher } \\
\text { rating }\end{array}$ & 1.42 & 1.782 & 2.11 & 1.937 & 1.82 & 1.940 & 1.360 & 2 & 0.507 \\
\hline & & $\begin{array}{l}\text { Parent } \\
\text { rating }\end{array}$ & 1.00 & 1.651 & 1.56 & 1.653 & 1.18 & 1.079 & 1.696 & 2 & 0.428 \\
\hline & \multirow{2}{*}{$\begin{array}{l}\text { Special } \\
\text { schools }\end{array}$} & $\begin{array}{l}\text { Teacher } \\
\text { rating }\end{array}$ & 2.58 & 1.792 & 3.10 & 1.619 & 1.04 & 1.364 & 17.671 & 2 & 0.0000 \\
\hline & & $\begin{array}{l}\text { Parent } \\
\text { rating }\end{array}$ & 2.17 & 1.899 & 2.50 & 1.147 & 1.83 & 1.946 & 3.888 & 2 & 0.143 \\
\hline \multirow{4}{*}{$\begin{array}{l}\text { Total be- } \\
\text { havioral prob- } \\
\text { lems score }\end{array}$} & \multirow{2}{*}{$\begin{array}{l}\text { Mainstream } \\
\text { schools }\end{array}$} & $\begin{array}{l}\text { Teacher } \\
\text { rating }\end{array}$ & 4.75 & 4.434 & 8.39 & 6.617 & 5.82 & 7.481 & 2.816 & 2 & 0.239 \\
\hline & & $\begin{array}{l}\text { Parent } \\
\text { rating }\end{array}$ & 6.08 & 6.788 & 10.22 & 7.175 & 6.45 & 5.429 & 2.198 & 2 & 0.333 \\
\hline & \multirow{2}{*}{$\begin{array}{l}\text { Special } \\
\text { schools }\end{array}$} & $\begin{array}{l}\text { Teacher } \\
\text { rating }\end{array}$ & 10.67 & 6.260 & 12.80 & 6.363 & 8.30 & 5.724 & 4.322 & 2 & 0.115 \\
\hline & & $\begin{array}{l}\text { Parent } \\
\text { rating }\end{array}$ & 11.57 & 7.450 & 12.35 & 5.967 & 10.74 & 5.887 & 2.175 & 2 & 0.337 \\
\hline \multirow{4}{*}{$\begin{array}{l}\text { Prosocial } \\
\text { behaviors }\end{array}$} & \multirow{2}{*}{$\begin{array}{l}\text { Mainstream } \\
\text { schools }\end{array}$} & $\begin{array}{l}\text { Teacher } \\
\text { rating }\end{array}$ & 7.83 & 2.480 & 7.00 & 2.657 & 7.55 & 2.207 & 0.777 & 2 & 0.678 \\
\hline & & $\begin{array}{l}\text { Parent } \\
\text { rating }\end{array}$ & 7.42 & 2.730 & 6.813 & 2.407 & 8.36 & 1.629 & 3.069 & 2 & 0.216 \\
\hline & \multirow{2}{*}{$\begin{array}{l}\text { Special } \\
\text { schools }\end{array}$} & $\begin{array}{l}\text { Teacher } \\
\text { rating }\end{array}$ & 5.96 & 2.236 & 7.05 & 2.259 & 7.83 & 2.037 & 7.804 & 2 & 0.020 \\
\hline & & $\begin{array}{c}\text { Parent } \\
\text { rating }\end{array}$ & 6.92 & 2.749 & 7.10 & 1.971 & 7.83 & 2.208 & 1.944 & 2 & 0.378 \\
\hline
\end{tabular}

Iranian Rehabilitation Journal

but correspond to reports from Heyl and Hintermair [26], O’Brennan et al. [27], Wiener [28], and Fathi et al. [29].

Heyl and Hintermair found that visually-impaired students' behavioral problems were less common at main- stream schools and that boys displayed more problems than girls [26]. O'Brennan et al. also indicated that students in special education systems obtained higher scores in attention and concentration problems and low- 
Table 5 . Comparison of behavioral problems and abilities among male students with a physical/motor disability at mainstream and special schools in terms of age groups

\begin{tabular}{|c|c|c|c|c|c|c|c|c|c|c|c|}
\hline \multirow{3}{*}{ SDQ scale } & & & \multicolumn{6}{|c|}{ Age } & \multirow{3}{*}{$\mathrm{X}^{2}$} & \multirow{3}{*}{ df } & \multirow{3}{*}{$\mathbf{P}$} \\
\hline & & & \multicolumn{2}{|c|}{ 7-8 Years } & \multicolumn{2}{|c|}{ 9-10 Years } & \multicolumn{2}{|c|}{ 11-12 Years } & & & \\
\hline & & & $M$ & SD & $M$ & SD & $M$ & SD & & & \\
\hline \multirow{4}{*}{$\begin{array}{l}\text { Emotional } \\
\text { symptoms }\end{array}$} & \multirow{2}{*}{$\begin{array}{l}\text { Mainstream } \\
\text { schools }\end{array}$} & $\begin{array}{l}\text { Teacher } \\
\text { rating }\end{array}$ & 1.94 & 2.487 & 1.92 & 1.881 & 1.71 & 1.546 & 0.095 & 2 & 0.954 \\
\hline & & $\begin{array}{l}\text { Parent } \\
\text { rating }\end{array}$ & 2.35 & 2.572 & 2.83 & 2.980 & 2.58 & 2.263 & 0.216 & 2 & 0.898 \\
\hline & \multirow{2}{*}{$\begin{array}{l}\text { Special } \\
\text { schools }\end{array}$} & $\begin{array}{l}\text { Teacher } \\
\text { rating }\end{array}$ & 2.54 & 2.734 & 1.62 & 1.876 & 2.88 & 2.279 & 0.095 & 2 & 0.954 \\
\hline & & $\begin{array}{l}\text { Parent } \\
\text { rating }\end{array}$ & 2.88 & 2.724 & 2.38 & 2.302 & 3.08 & 3.081 & 0.655 & 2 & 0.721 \\
\hline \multirow{4}{*}{$\begin{array}{l}\text { Conduct } \\
\text { problems }\end{array}$} & \multirow{2}{*}{$\begin{array}{l}\text { Mainstream } \\
\text { schools }\end{array}$} & $\begin{array}{l}\text { Teacher } \\
\text { rating }\end{array}$ & 0.47 & 0.717 & 0.92 & 1.379 & 0.92 & 1.776 & 3.374 & 2 & 0.158 \\
\hline & & $\begin{array}{l}\text { Parent } \\
\text { rating }\end{array}$ & 0.59 & 0.939 & 1.33 & 1.614 & 0.71 & 0.806 & 2.506 & 2 & 0.286 \\
\hline & \multirow{2}{*}{$\begin{array}{l}\text { Special } \\
\text { schools }\end{array}$} & $\begin{array}{l}\text { Teacher } \\
\text { rating }\end{array}$ & 1.79 & 1.503 & 1.54 & 1.739 & 2.12 & 1.563 & 3.664 & 2 & 0.160 \\
\hline & & $\begin{array}{l}\text { Parent } \\
\text { rating }\end{array}$ & 2.21 & 1.560 & 1.84 & 1.405 & 1.96 & 1.541 & 0.683 & 2 & 0.711 \\
\hline \multirow{4}{*}{ ADHD } & \multirow{2}{*}{$\begin{array}{l}\text { Mainstream } \\
\text { schools }\end{array}$} & $\begin{array}{l}\text { Teacher } \\
\text { rating }\end{array}$ & 1.59 & 1.622 & 2.92 & 2.746 & 2.63 & 1.740 & 3.547 & 2 & 0.170 \\
\hline & & $\begin{array}{l}\text { Parent } \\
\text { rating }\end{array}$ & 2.59 & 2.002 & 3.50 & 2.939 & 2.46 & 2.167 & 1.027 & 2 & 0.559 \\
\hline & \multirow{2}{*}{$\begin{array}{l}\text { Special } \\
\text { schools }\end{array}$} & $\begin{array}{l}\text { Teacher } \\
\text { rating }\end{array}$ & 3.96 & 2.528 & 4.32 & 2.461 & 4.60 & 2.754 & 1.174 & 2 & 0.556 \\
\hline & & $\begin{array}{l}\text { Parent } \\
\text { rating }\end{array}$ & 5.00 & 2.282 & 4.76 & 2.454 & 5.60 & 3.266 & 0.659 & 2 & 0.719 \\
\hline \multirow{4}{*}{$\begin{array}{l}\text { Peer prob- } \\
\text { lems }\end{array}$} & \multirow{2}{*}{$\begin{array}{l}\text { Mainstream } \\
\text { schools }\end{array}$} & $\begin{array}{l}\text { Teacher } \\
\text { rating }\end{array}$ & 1.18 & 1.380 & 1.58 & 1.929 & 1.67 & 1.633 & 1.097 & 2 & 0.578 \\
\hline & & $\begin{array}{l}\text { Parent } \\
\text { rating }\end{array}$ & 094 & 0.827 & 1.25 & 2.050 & 1.38 & 1.498 & 0.576 & 2 & 0.750 \\
\hline & \multirow{2}{*}{$\begin{array}{l}\text { Special } \\
\text { schools }\end{array}$} & $\begin{array}{l}\text { Teacher } \\
\text { rating }\end{array}$ & 2.17 & 1.532 & 2.03 & 1.641 & 2.88 & 2.108 & 2.637 & 2 & 0.268 \\
\hline & & $\begin{array}{l}\text { Parent } \\
\text { rating }\end{array}$ & 2.63 & 1.884 & 2.30 & 1.681 & 2.52 & 1.939 & 0.559 & 2 & 0.756 \\
\hline \multirow{4}{*}{$\begin{array}{c}\text { Total } \\
\text { behavioral } \\
\text { problems } \\
\text { score }\end{array}$} & \multirow{2}{*}{$\begin{array}{l}\text { Mainstream } \\
\text { schools }\end{array}$} & $\begin{array}{l}\text { Teacher } \\
\text { rating }\end{array}$ & 5.18 & 6.953 & 7.33 & 6.880 & 6.92 & 4.232 & 1.778 & 2 & 0.411 \\
\hline & & $\begin{array}{l}\text { Parent } \\
\text { rating }\end{array}$ & 6.47 & 5.001 & 8.92 & 7.242 & 7.13 & 4.928 & 0.652 & 2 & 0.722 \\
\hline & \multirow{2}{*}{$\begin{array}{l}\text { Special } \\
\text { schools }\end{array}$} & $\begin{array}{l}\text { Teacher } \\
\text { rating }\end{array}$ & 10.46 & 5.634 & 9.51 & 5.952 & 12.48 & 7.269 & 3.481 & 2 & 0.175 \\
\hline & & $\begin{array}{l}\text { Parent } \\
\text { rating }\end{array}$ & 12.71 & 6.868 & 11.27 & 5.848 & 12.68 & 6.750 & 0.999 & 2 & 0.607 \\
\hline \multirow{4}{*}{$\begin{array}{l}\text { Prosocial } \\
\text { behaviors }\end{array}$} & \multirow{2}{*}{$\begin{array}{l}\text { Mainstream } \\
\text { schools }\end{array}$} & $\begin{array}{l}\text { Teacher } \\
\text { rating }\end{array}$ & 7.29 & 2.257 & 7.42 & 2.151 & 6.79 & 2.167 & 0.647 & 2 & 0.714 \\
\hline & & $\begin{array}{l}\text { Parent } \\
\text { rating }\end{array}$ & 6.65 & 1.801 & 7.25 & 1.442 & 6.83 & 2.390 & 1.078 & 2 & 0.583 \\
\hline & \multirow{2}{*}{$\begin{array}{l}\text { Special } \\
\text { schools }\end{array}$} & $\begin{array}{l}\text { Teacher } \\
\text { rating }\end{array}$ & 6.42 & 2.083 & 5.43 & 2.340 & 6.08 & 2.886 & 2.048 & 2 & 0.305 \\
\hline & & $\begin{array}{l}\text { Parent } \\
\text { rating }\end{array}$ & 6.46 & 2.919 & 5.70 & 3.290 & 6.44 & 2.815 & 1.049 & 2 & 0.592 \\
\hline
\end{tabular}

Iranian Rehabilitation Journal

er scores in emotion regulation skills than those in general education [27].

Wiener and Tardif suggested that students with special learning disabilities receive four different types of training: support classes and reference rooms for children with mild impairment and special and main-stream classes for children with further disabilities. Children who received education at mainstream and support classes had fewer behavioral problems than those at reference and special classes. In addition, behavioral problem scores in these four types of training were higher in special education 
than other types of training, and the social skills of students attending mainstream schools were greater in comparison to other types of training [28].

Fathi et al. showed that there was a significant difference between the behavioral problems of blind and deaf students at mainstream and special schools. Students differed in all aspects of behavioral problems in the Teacher Version of Achenback's Questionnaire, except for anxiety, isolation and physical problems at both types of schools and the mean scores of behavioral disorders at mainstream schools was lower than that of special schools [29].

Additionally, the findings of this study also indicated that there was a significant difference between the behavioral skills (prosocial behaviors) of students with a physical/motor disability at the mainstream and special schools from teachers' perspective. Accordingly, the behavioral skills of students at special schools were lower, but there was no significant difference between behavioral skills according to the parents.

Our findings confirmed the results of Karsten's study [30]. Karsten et al. conducted a study to compare the social behaviors and academic skills of students at both mainstream and special schools and concluded that the social behaviors of students at both schools were significantly different and the level of psychosocial skills was more favorable at mainstream schools [30].

Another important finding in the present study was the significant difference in behavioral skills between girls and boys with physical/motor disability at mainstream and special schools. Our findings suggest that there was a significant difference in terms of the total behavioral problems scales among female students at both schools, and the female students displayed behavioral problems more frequently at special schools. There was also a significant difference in terms of the attention deficit/hyperactivity scale; however, the difference in emotional symptoms and conduct problems was only noted by teachers, and there was no significant difference from the parents' perspective. There was also a difference in terms of peer relationship problems according to parents, but the teachers did not report any obvious differences. Moreover, there was no significant difference in behavioral skills among female students at mainstream and special schools according to both teachers and parents.

Further interpretations from this study pointed out a significant difference in the levels of behavioral problems, attention deficit/hyperactivity, peer relationship problems and total scale of behavioral problems among male and female students at mainstream and special schools, though, no significant difference was observed for the emotional symptoms. The results also suggested that there was a significant difference between male and female students in behavioral skills at mainstream and special schools according to teachers, but not parents.

The findings of this study are in contradiction with the studies of Farajullahi [24] and Meshkani [25] but in line with the findings of Buckley [31] and Hemmati [32]. Buckley et al. showed that the behavioral problems of boys with Down's Syndrome (DS) were related to the type of school and that students' behavioral problems at mainstream schools were less than those observed at special schools. Some behavioral problems (25\%) of students at mainstream schools were at the moderate level and $12 \%$ of their problems were serious whereas these values were $27 \%$ and $32 \%$ for students at special schools, respectively. On the other hand, there was no significant difference among the adolescents at special schools in terms of conduct problems and attention and concentration problems [31]. Hemmati et al. showed that social skills of the adolescents with DS at regular schools grew more favorably in comparison with their counterparts who studied at special schools [32].

\section{Conclusion}

Our study clearly indicates that disabled students' behavioral problems are lower and their behavioral skills are higher at mainstream schools. The present study supports the provision of mainstream education for these students. Therefore, it is recommended to provide the possibility of integrating disabled students' education at regular schools. We hope that findings from our research study will be another step towards forward in promoting mainstream education and increasing the presence of disabled students (including physically disabled students) at regular schools.

\section{Acknowledgments}

This paper was extracted from the MSc. thesis of the first author in the Department of Psychology and Education of Exceptional Children, University of Social Welfare and Rehabilitation Sciences, Tehran The authors would like to thank all the teachers and parents who participated in this study for their contribution.

\section{Conflict of Interest}

The authors declare no conflicts of interest. 


\section{References}

[1] Altun C, Guven G, Akgun OM, Akkurt MD, Basak F, Akbulut E. Oral health status of disabled individuals attending special schools. European Journal of Dentistry. 2010; 4(4):3616. PMCID: PMC2948746

[2] Sharifi M, Younesi SJ, Movallali G, Mohammad-Aminzadeh D, Rostami M. Needs and problems of students with physicalmotor disabilities in transportation, communication, bullying and leisure-time. Asian Journal of Education and e-Learning. 2015; 3(4):297-305.

[3] Lewis Brown R, Turner RJ. Physical disability and depression: Clarifying racial/ethnic contrasts. Journal of Aging and Health. 2010; 22(7):977-1000. doi: 10.1177/0898264309360573

[4] Hill Briggs F, Dial JG, Morere DA, Joyce A. Neuropsychological assessment of persons with physical disability, visual impairment or blindness, and hearing impairment or deafness. Archives of Clinical Neuropsychology. 2007; 22(3):389404. doi: 10.1016/j.acn.2007.01.013

[5] Von der Luft G. Self concept in children with cerebral palsy [PhD dissertation]. Pennsylvania: Temple University; 2006.

[6] Sartawi A, AlMuhairy O, Abdat R. Behavioral problems among students with disabilities in United Arab Emirates. International Journal for Research in Education. 2011; 29:1-5.

[7] Dababneh KA. The socio-emotional behavioural problems of children with cerebral palsy according to their parents' perspectives. International Journal of Adolescence and Youth. 2013; 18(2):85-104. doi: 10.1080/02673843.2012.655443

[8] Jones SE, Lollar DJ. Relationship between physical disabilities or long-term health problems and health risk behaviors or conditions among US high school students. Journal of School Health. 2008; 78(5):252-7. doi: 10.1111/j.1746-1561.2008.00297.x

[9] Bjorgaas HM, Elgen I, Boe T, Hysing M. Mental health in children with cerebral palsy: Does screening capture the complexity. The Scientific World Journal. 2013; 2013:1-7. doi: $10.1155 / 2013 / 468402$

[10] Brossard Racine M, Hall N, Majnemer A, Shevell MI, Law $\mathrm{M}$, Poulin C, et al. Behavioural problems in school age children with cerebral palsy. European Journal of Paediatric Neurology. 2012; 16(1):35-41. doi: 10.1016/j.ejpn.2011.10.001

[11] Naugler JJ. A comparison of friendship patterns of children with physical disabilities in integrated and segregated school settings [PhD dissertation]. Ottawa: National Library of Canada; 1999.

[12] Weicker B. Students in need: Benefits and challenges of a special education school. Hartford: Trinity College; 2012.

[13] Nketsia W. Teacher education and inclusion in Ghana: Preservice teachers' preparedness for creating an inclusive classroom [Master's theses]. Jyväskylä: University of Jyväskylä; 2011.

[14] Paleeri S. Educational programmes for children with cerebral palsy: Parents' and teachers' dilemma. Journal of Education and Practice. 2010; 1(3):9-15.

[15] Qu X. Understanding special school provision for children with severe learning difficulties in relation to inclusive educa- tion. Cambridge Open-Review Educational Research e-Journal. 2015; 1(2):78-98

[16] Santos LHC dos, Grisotto KP, Rodrigues DCB, Bruck I. Inclusão escolar de crianças e adolescentes com paralisia cerebral: esta é uma realidade possível para todas elas em nossos dias. Revista Paulista de Pediatria. 2011; 29(3):314-9. doi: 10.1590/s0103-05822011000300002

[17] Knight KH, Porcellato L, Tume L. Out-of-school lives of physically disabled children and young people in the United Kingdom. Journal of Child Health Care. 2013; 18(3):275-85. Doi: $10.1177 / 1367493513490446$

[18] Hocutt AM. Effectiveness of special education: Is placement the critical factor. The Future of Children. 1996; 6(1):77. doi: $10.2307 / 1602495$

[19] Moreno J, Aguilera A, Saldana D. Do Spanish parents prefer special schools for their children with Autism. Education and Training in Developmental Disabilities. 2008:162-73.

[20] Goodman R, Ford T, Simmons H, Gatward R, Meltzer H. Using the Strengths and Difficulties Questionnaire (SDQ) to screen for child psychiatric disorders in a community sample. British Journal of Psychiatry. 2000; 177(06):534-9. doi 10.1192/bjp.177.6.534

[21] Goodman R. The strengths and difficulties questionnaire: A research note. Journal of Child Psychology and Psychiatry. 1997; 38(5):581-6. doi: 10.1111/j.1469-7610.1997.tb01545.x

[22] Palmieri PA, Smith GC. Examining the structural validity of the Strengths and Difficulties Questionnaire (SDQ) in a U.S. sample of custodial grandmothers. Psychological Assessment. 2007; 19(2):189-98. doi: 10.1037/1040-3590.19.2.189

[23] Goodman A, Lamping DL, Ploubidis GB. When to use broader internalising and externalising subscales instead of the hypothesised five subscales on the Strengths and Difficulties Questionnaire (SDQ): Data from British parents, teachers and children. Journal of Abnormal Child Psychology. 2010 38(8):1179-91. doi: 10.1007/s10802-010-9434-x

[24] Farajullahi M, Sarmadi MR, Taghdiri Nooshabadi A. Academic achievement and behavioral difficulties in male students with hearing loss in exceptional and integrated schools. Journal of Exceptional Children. 2009; 9(3):273-81.

[25] Moshkani M. Comparison of academic achievement and behavior of hearing damage students in special and mainstream schools. Journal of Exceptional Education. 2004; 60(1):31-8.

[26] Heyl V, Hintermair M. Executive function and behavioral problems in students with visual impairments at mainstream and special schools. Journal of Visual Impairment \& Blindness. 2015; 109(4):251-63.

[27] O'Brennan LM, Waasdorp TE, Pas ET, Bradshaw CP. Peer victimization and social-emotional functioning. Remedial and Special Education. 2015; 36(5):275-85. doi: $10.1177 / 0741932515575615$

[28] Wiener J, Tardif CY. Social and emotional functioning of children with learning disabilities: Does special education placement make a difference. Learning Disabilities Research and Practice. 2004; 19(1):20-32. doi: 10.1111/j.15405826.2004.00086.x 
[29] Fathi D, Keshavarzi Arshadi F, Jamali Firoozabadi M, Massah Choolaby O. [Comparison of behavioral disorders, compromise behaviors and academic achievement of exceptional students in especial educational system and integrated educational system (Persian)]. Journal of Rehabilitation. 2011; 12(1):48-55.

[30] Karsten S, Peetsma T, Roeleveld J, Vergeer M. The Dutch policy of integration put to the test: differences in academic and psychosocial development of pupils in special and mainstream education. European Journal of Special Needs Education. 2001; 16(3):193-205. doi: 10.1080/08856250110074364

[31] Buckley S, Bird G, Sacks B, Archer T. A comparison of mainstream and special education for teenagers with Down syndrome: Implications for parents and teachers. Down Syndrome Research and Practice. 2006; 9(3):54-67. doi: 10.3104/ reports. 295

[32] Tajrishi M, Rasafyani M, Tymori R. [Comparison of emotional maturity in boy, s adolescents with Down Syndrome (Research in normal and exceptional schools) (Persian)]. Journal of Rehabilitation. 2014; 14(6):87-92. 
